\title{
DOES THE OXIDATION OF METHIONINE RESIDUE PRECEDE THE INACTIVATION OF THE TRYPSIN INHIBITOR (LUTI) IN GERMINATING SEEDS OF COMMON FLAX (LINUM USITATISSIMUM)?
}

\author{
IRENA LORENC-KuBIS, AGNIESZKA CZERWIŃSKA-GOLEŃ, \\ JOLANTA KOWALSKA, TADEUSZ WILUSZ \\ Institute of Biochemistry and Molecular Biology, University of Wrocław \\ Tamka 2, 50-137 Wrocław, Poland \\ e-mail: lorenc@bf.uni.wroc.pl
}

(Received: March 28, 2003. Accepted: July 15, 2003)

\begin{abstract}
Antitrypsin activity in germinating common seeds of flax (Linum usitatissimum) was investigated. At the early stage of germination an increase in antitrypsin activity was observed, followed by its decrease during the development of the seedlings. From 6-day-old seedlings a trypsin inhibitor (gerLUTI) was purified. The purification procedure involved fractionation of proteins from seedling homogenate with alcohol and successive chromatography on CM-Sephadex C-25 on immobilised methylchymotrypsin in the presence of $5 \mathrm{M} \mathrm{NaCl}$, and finally on a $\mathrm{C} 18$ column in RP-HPLC.

The gerLUTI migrated in SDS PAGE as a single band, but in mass spectroscopy analysis it exhibited the presence of at least three forms with molecular masses of $7654 \pm 3 \mathrm{Da}, 7668 / 7670 \pm 3 \mathrm{Da}$, and $7687 \pm 3 \mathrm{Da}$. The preparation of LUTI isolated from resting seeds contained only one form, with a molecular mass of $7655 \pm 3$ Da. LUTI and gerLUTI differed also in methionine contents. LUTI contained two methionine residues, whereas in gerLUTI only a trace of methionine was detected. The obtained results might suggest that during flax seeds germination the inhibitor molecules undergo selective modification, e.g. oxidation at methionine residues, before being degraded by proteolytic enzymes.
\end{abstract}

KEY WORDS: Linum usitatissimum seedlings, trypsin inhibitor, protein, germination, immobilised methylchymotrypsin, mass spectra.

\section{INTRODUCTION}

Plants and seeds contain considerable amounts of proteins and peptides inhibiting serine proteinase activity. The role of these inhibitors in the physiology of the plant is not fully understood. They may be involved in the regulation of endogenous proteinases during seed dormancy, in the mechanism of reserve protein mobilisation (McGrain et al. 1992), or they may protect plants against herbivorous pests and pathogens (Wolfson and Murdock 1995).

Most of serine protease inhibitors of plant origin are small proteins of molecular weight rarely exceeding 20 $\mathrm{kDa}$. They were isolated from the seeds of Leguminosea, Gramineae, Solanaceae (Richardson 1991), Cruciferaea (Volpicelleae 2000), Cucurbitaceae (Wieczorek et al. 1985), Alismaceae (Luo et al. 1997), Amaranthaceae (Hejgaard et al. 1994), Compositae (Luckett et al. 1999) and Linaceae (Lorenc-Kubis et al. 2001).

In a previous paper (Lorenc-Kubis et al. 2001) we reported on the purification of a trypsin inhibitor (LUTI) from the resting seeds of common flax (Linum usitatissimum). The inhibitor consists of a single polypeptide chain of 69 residues with one disulfide bridge; its NMR solution structure has been determined (Cierpicki and Otlewski 2000). LUTI shows a high level of sequence similarity to the potato I inhibitor family, and it is the first serine proteinase inhibitor isolated from Linaceae.

Seed germination and growth of young seedlings are characterised by the breakdown of seed reserve proteins. The breakdown is accompanied both by an enhancement of proteolytic activity, and by a decrease in the activity of protease inhibitors (Chrispeels and Baumgartner 1978), but still we do not know the details of these processes.

The following is an account of our study of the changes in antitrypsin activity in germinating flax seeds, and of the purification and partial characterisation of the trypsin inhibitor (gerLUTI - Linum usitatissimum trypsin inhibitor from germinating seeds) from the seeds germinated for 6 days. 


\section{MATERIALS}

The seeds of Linum usitatissimum were supplied by Plant Seeds Corporation PPHU „ROLMAK” from Staszów, Poland. Bovine trypsin (EC 3.4.21.4) was prepared according to Wilimowska-Pelc and Mejbaum-Katzenellenbogen (1978). Bovine a-chymotrypsin (EC 3.4.21.1), $N$ - $\alpha$-benzoyl-DL-Arg $p$-nitroanilide (BAPNA), Coomassie Brilliant Blue R-250, bovine serum albumin (BSA), divinyl sulfone, molecular weight markers for SDS-PAGE were from Sigma (St. Louis, MO, USA). Methylchymotrypsin was obtained by the method of Nagawa and Bender (1970). Sepharose 4B and CM-Sephadex C-25 were from Pharmacia LKB Biotechnology (Uppsala, Sweden); acetonitrile (HPLC grade), trifluoroacetic acid (TFA), reagents for PAGE and edestin were from ICN Biomedicals (Costa Mesa, CA, USA); YM 3 membrane filters were purchased from Amicon (Danvers, MA, USA). All other reagents were of analytical grade. A reverse phase Delta PAK $\mathrm{C}_{18}$ column was from Waters Division of Millipore (USA).

\section{METHODS}

\section{Germination of the seeds}

The study was carried out on seeds and seedlings of common flax. The seeds were rinsed with water for 24 hours, sown in a moist germination bed of filter paper and allowed to germinate at $24^{\circ} \mathrm{C}$ for 10 days with $10-12$ hours of daylight. The seedlings were harvested after 1, 2, 3, 4, 5, $6,8,11$ and 13 days. No fungal contamination was observed on the germinating seeds

\section{Extraction of proteins}

Ground seeds $(4 \mathrm{~g})$ were homogenised with 10 volumes and seedlings with 5 volumes $(\mathrm{w} / \mathrm{v})$ of $0.1 \mathrm{M}$ sodium acetate buffer, $\mathrm{pH}$ 5.1. The extraction was performed at $4^{\circ} \mathrm{C}$ for 1 hour with constant mechanical stirring. After centrifugation (for $20 \mathrm{~min}$ at $12000 \times \mathrm{g}$ ) the pellet was discarded and the supernatant was used for the analysis of inhibitory activity.

\section{ANALYTICAL METHODS}

\section{Measurement of enzyme and inhibitor activities}

Enzyme activities were measured spectrophotometrically at $410 \mathrm{~nm}$ after $10 \mathrm{~min}$. incubation at $25^{\circ} \mathrm{C}$ in $0.05 \mathrm{M}$ Tris$\mathrm{HCl}$ buffer, pH 8.0, with $20 \mathrm{mM} \mathrm{CaCl}_{2}$, using BAPNA as a substrate for trypsin (Erlanger et al. 1961). Enzymatic reactions were terminated by the addition of $0.5 \mathrm{ml}$ of $30 \%$ acetic acid. One unit of inhibitory activity was defined as the amount of protein required to reduce the activity of 2 $\mu \mathrm{g}$ of an enzyme to $50 \%$ of the original value.

\section{Protein determination}

Protein was estimated by either microbiuret method of Goa (1953) using bovine albumin as a standard, or by spectrophotometric measurement of the absorbance at 215 $\left(\mathrm{A}_{215}\right)$ and $225\left(\mathrm{~A}_{225}\right) \mathrm{nm}$, and calculation of the concentration $c$ by using the following equation (Wolf 1983):

$$
c[\mu \mathrm{g} \mathrm{mL}-1]=144\left(\mathrm{~A}_{215}-\mathrm{A}_{225}\right)
$$

\section{Immobilisation of methylchymotrypsin}

Methylchymotrypsin ( $1 \mathrm{~g}$ ) was immobilised on divinylsulfone-activated Sepharose 4B (70 ml) according to Pepper (1992).

\section{Polyacrylamide gel electrophoresis (PAGE)}

Samples of protein were subjected to electrophoresis on $16.5 \%$ gels in the presence of SDS according to Schägger and von Jagow (1987).

\section{Amino acid analysis}

Samples containing 1-5 $\mu \mathrm{g}$ of protein were hydrolysed by vapour-phase $\mathrm{HCl}$ hydrolysis at $112^{\circ} \mathrm{C}$ for 20 hours in a protein hydrolyser (Knauer, Germany). The hydrolysis was followed by manual derivatization with 6-aminoquinolyl- $N$-hydroxysuccinimidyl carbamate (Cohen and $\mathrm{Mi}-$ chaud 1993). The AQC-derivatives of amino acids were separated by HPLC on an AccQ. Tag column $(160 \times 3.9$ mm i.d.; Waters, USA).

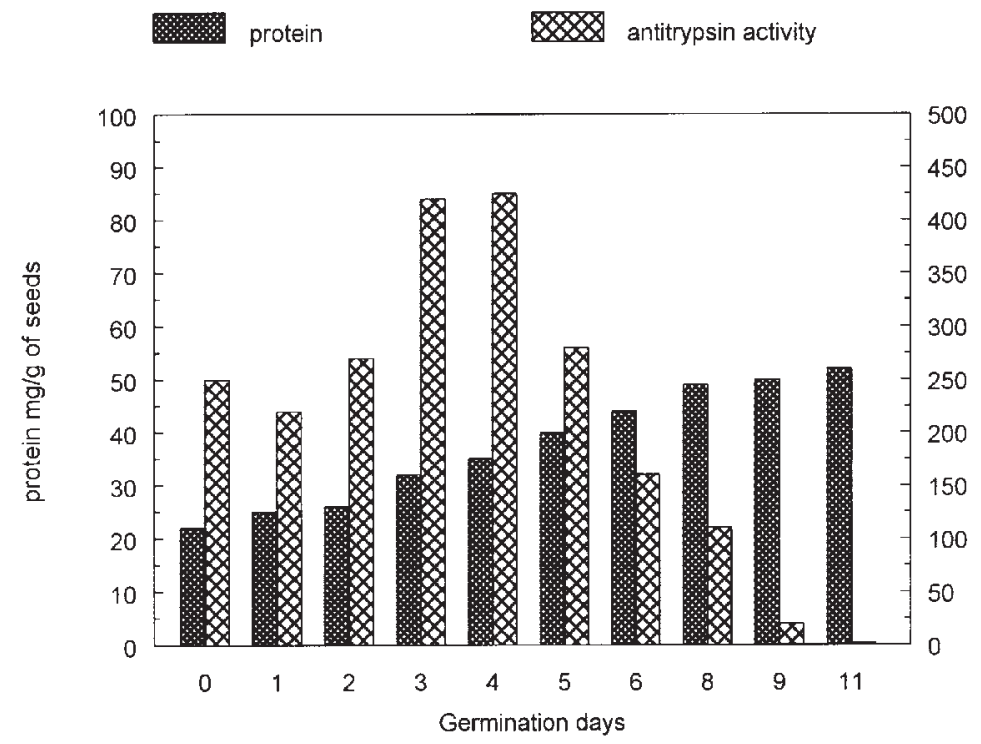

Fig. 1. Changes in protein content and antitrypsin activity in seedlings at different development stages. Data are the mean of four replications. Protein content and inhibitory activity were calculated per 75 seedlings, which corresponds to $1 \mathrm{~g}$ of dry resting seeds. 


\section{Mass spectrometry}

Mass spectra were recorded on a Finnagan MAT TSQ 700 triple-stage quadrupole mass spectrometer equipped with an electrospray ion source (ESI-MS). Samples were dissolved in methanol/water/acetic acid (50:45:5, v/v/v) and introduced into the electrospray needle by mechanical infusion through a microsyringe at a flow rate of $2 \mu 1 \mathrm{~min}^{-}$ 1. A potential difference of $4.5 \mathrm{kV}$ was applied between the electrospray needles. Nitrogen gas (99.9\% pure) was used to evaporate the solvent from the charged droplets. At least twenty scans were averaged to obtain each spectrum. Transformations of the resulting spectra were performed with the BioWorks software package (Finnigan MAT).

\section{RESULTS AND DISCUSSION}

\section{Antitrypsin activity of the developing seedlings of common flax}

Proteins from resting and imbibed seeds and developing seedlings (1-10 days old) were extracted with $0.1 \mathrm{M}$ acetate buffer, $\mathrm{pH} 5.1$, and antitrypsin activity was monitored during seeds germination and seedlings development (Fig. 1). During the first two days of germination an increase in antitrypsin activity was observed. It was probably due to the more efficient extraction of the inhibitor after the imbibition of the seeds On the 6th day of germination the amount of the inhibitor markedly decreased and, finally, on the 13th day no traces of the activity were detected. Until the 8th day of germination the amount of protein soluble at $\mathrm{pH}$ 5.1 gradually increased.

\section{Isolation of the inhibitor from the seedlings}

From $320 \mathrm{~g}$ of 6-day-old seedlings we isolated the trypsin inhibitor following the previously published procedure (Lorenc-Kubis et al. 2001). The seedlings were homogenised with 5 volumes $(\mathrm{w} / \mathrm{v})$ of $0.1 \mathrm{M}$ sodium acetate buffer, $\mathrm{pH} 5.1$, stirred for 1 hour at $4^{\circ} \mathrm{C}$, then clarified by centrifugation. Proteins were precipitated with $80 \%$ ethanol and collected by centrifugation, solubilized in distilled water, dialysed against $0.1 \mathrm{M}$ acetate buffer, $\mathrm{pH} 5.5$, and applied to a CM-Sephadex C-25 column. The inhibitor from seedlings, contrary to the preparation obtained from resting seeds (Lorenc-Kubis et al. 2001), was not very well separated from inactive proteins (Fig. 2). Active fractions were pooled, adjusted to $\mathrm{pH} 7.5$ with $2 \mathrm{M}$ Tris, and $\mathrm{NaCl}$ was added to the final concentration of $5 \mathrm{M}$. The solution was applied to a column with immobilised methylchymotrypsin, equilibrated with $0.05 \mathrm{M}$ Tris- $\mathrm{HCl}$ buffer, $\mathrm{pH} 7.5$, containing $5 \mathrm{M} \mathrm{NaCl}$. In the presence of high $\mathrm{NaCl}$ concentration all antitrypsin activity was adsorbed onto the affinity column and, alike the inhibitor from the resting flaxseeds, it was eluted in two peaks: first with water, and second with $0.01 \mathrm{M} \mathrm{HCl}$ (Fig. 3).

In the case of the inhibitor of the resting seeds (LUTI) (Lorenc-Kubis et al. 2001), both inhibitory peaks I and II turned out to be identical proteins, that is why we focused our further study on seedlings inhibitor I (gerLUTI I). The inhibitor preparation was desalted on a YM 3 membrane filter and chromatographed by reverse-phase HPLC. On a $\mathrm{C}_{18}$ column gerLUTI I separated into 3 peaks, designated as gerLUTI Ia, gerLUTI Ib and gerLUTI Ic (Fig. 4). The first two fractions were not well separated from each other

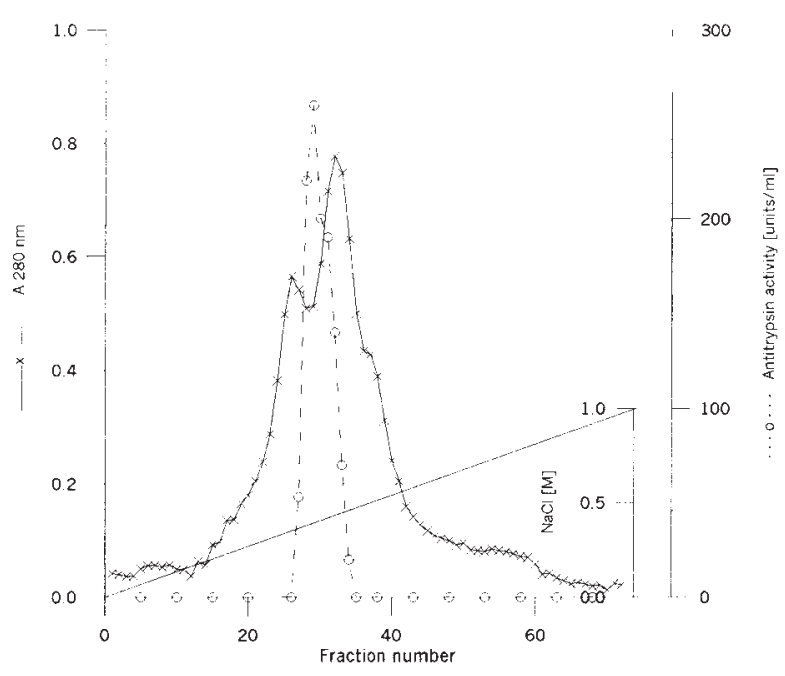

Fig. 2. CM-Sephadex C 25 chromatography of ethanol-precipitated protein from 5-day-old seedlings. Protein precipitated with $80 \%$ ethanol and resolved in $0.1 \mathrm{M}$ acetate buffer, $\mathrm{pH} 5.5$, was loaded on a column $(22 \times$ $170 \mathrm{~mm}$ ), equilibrated with $0.1 \mathrm{M}$ acetate buffer, $\mathrm{pH}$ 5.5. Elution was developed with $\mathrm{NaCl}$ gradient $(0.0$ to $1.0 \mathrm{M})$. Fractions $(5 \mathrm{ml})$ were collected and analysed for protein and antitryptic activity. Fractions from 28 to 34 were pooled and chromatographed on immobilised metylchymotrypsin.

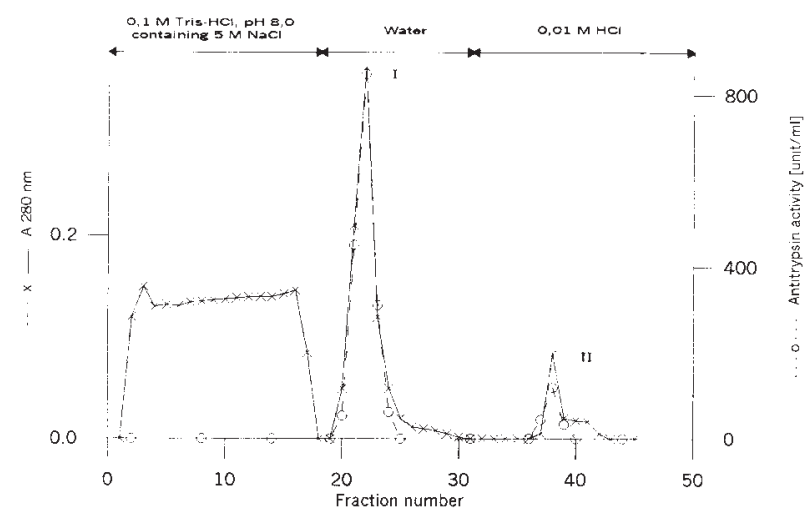

Fig. 3. Affinity chromatography of trypsin inhibitor from flax seedlings on immobilised methylchymotrypsin. A sample of $30 \mathrm{ml}(500 \mathrm{mg}$ of protein) containing $5 \mathrm{M} \mathrm{NaCl}$ in $0.1 \mathrm{M}$ Tris- $\mathrm{HCl}$ buffer, $\mathrm{pH} 8.0$, was loaded on a methylchymotrypsin-Sepharose $4 \mathrm{~B}$ column $(8 \times 120 \mathrm{~mm})$ equilibrated with a starting buffer containing $5 \mathrm{M} \mathrm{NaCl}$. The column was intensively equilibrated with the buffer containing $5 \mathrm{M} \mathrm{NaCl}$ until the $\mathrm{A}_{280}$ dropped below 0.02. Finally, the inhibitor was eluted first with water (peak I), followed by $0.01 \mathrm{M} \mathrm{HCl}$ (peak II). Fractions of $4 \mathrm{ml}$ were collected at a flow rate of $140 \mathrm{ml} / \mathrm{h}^{-1}$.

therefore they were rechromatographed under the same conditions (not shown).

\section{Characterisation of the inhibitor}

The amino acid compositions of gerLUTI Ia, Ib and Ic were compared with the resting seed inhibitor (LUTI). The only difference concerned the methionine residues. LUTI contained 2 methionine residues (positions 20 and 43 in Fig. 7), whereas the inhibitor preparations from germinating seeds were essentially deprived of methionine content (Table 1).

The U.V. absorption spectra of gerLUTI Ia, Ib, and Ic were very similar to each other with the maximum at 275 nm (not shown). 


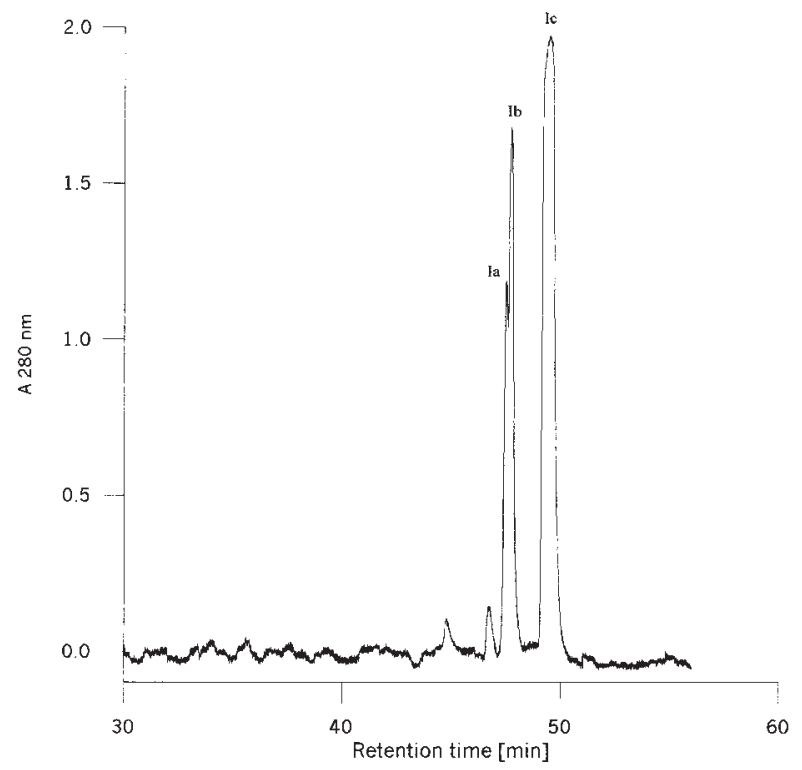

Fig. 4. RP-HPLC of the inhibitor $(80 \mu \mathrm{g}$ from peak I after affinity chromatography) on a Nucleosil $100 \mathrm{C}_{18}$ column $(10 \mu \mathrm{m} ; 250 \times 8.0 \mathrm{~mm}$ i.d.). The proteins were eluted with acetonitrile (linear gradient in $0.1 \%$ TFA).

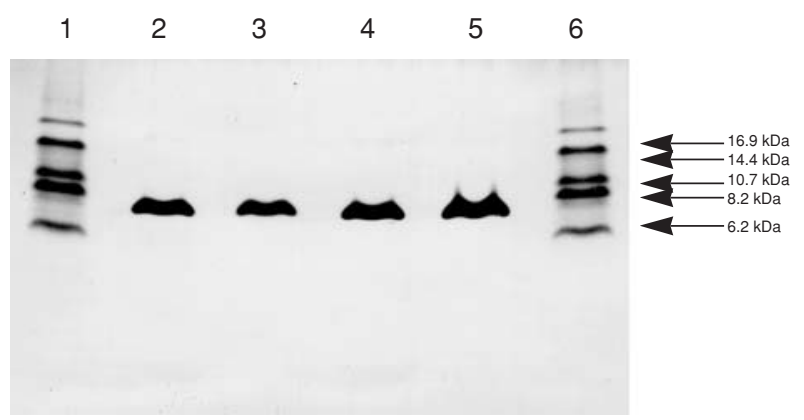

Fig. 5. SDS-PAGE of the trypsin inhibitors from resting (LUTI) and germinating flax seeds (gerLUTI I-peak I after affinity chromatography). Lanes 1 and 6: molecular weight markers; lane 2: LUTI (15 $\mu \mathrm{g})$; lane 3: gerLUTI Ia $(10 \mu \mathrm{g})$; lane 4: gerLUTI Ib $(10 \mu \mathrm{g})$; and line 5: gerLUTI Ic $(10 \mu \mathrm{g})$.

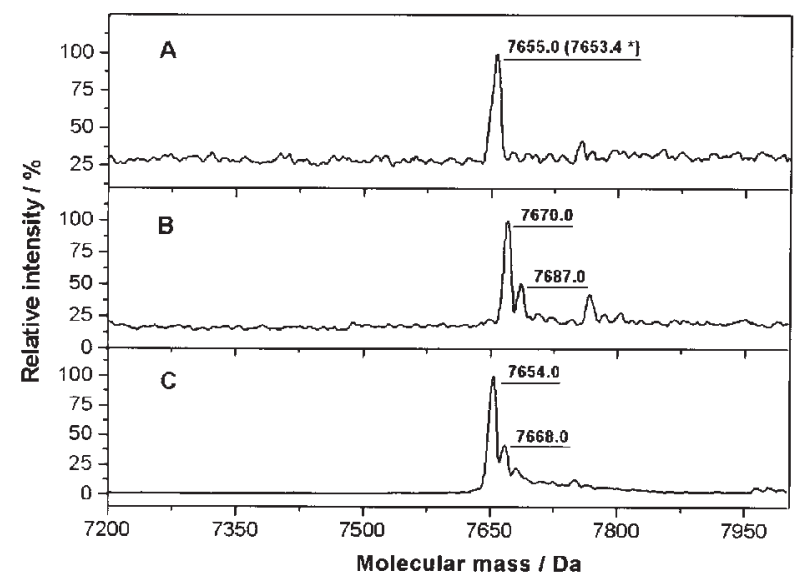

Fig. 6. Mass spectra (electrospray ionisation) of HPLC purified: (A) LUTI from resting seeds; (B) gerLUTI I b; (C) gerLUTI Ic. *Molecular weight calculated according to amino acid sequence.

During electrophoresis in the presence of sodium dodecyl sulfate under reducing conditions all three preparations: gerLUTI Ia, Ib and Ic, migrated as a single band and had a mobility similar to LUTI from the resting seeds (Fig. 5); calculated molecular masses were about $7600 \mathrm{Da}$.

To better characterise preparations of the two main peaks: gerLUTI Ib and Ic, mass spectrometric analysis was performed. The mass spectra of gerLUTI Ib and Ic showed the presence of several closely related proteins slightly differing in molecular masses. The gerLUTI Ic preparation, besides the protein with a molecular mass of $7654 \pm 3 \mathrm{Da}$, which might have corresponded to LUTI from the resting seeds (7653.4 Da calculated from amino acid sequence analisis) Lorenc-Kubis I. et al. 2001), contained a distinctly „heavier" peak with a molecular weight of $7668 \pm 3 \mathrm{Da}$ (plus $14.6 \pm 3 \mathrm{Da}$ ). The gerLUTI Ib did not contain an inhibitor with a molecular mass corresponding to LUTI from the resting seeds at all, instead, in the preparation dominated a protein with a molecular mass of $7670 \pm 3 \mathrm{Da}$ (plus

TABLE 1. Amino acid composition of LUTI from resting seeds and gerLUTI Ia, Ib and Ic from germinating seed. In the parentheses the nearest integer values are given.

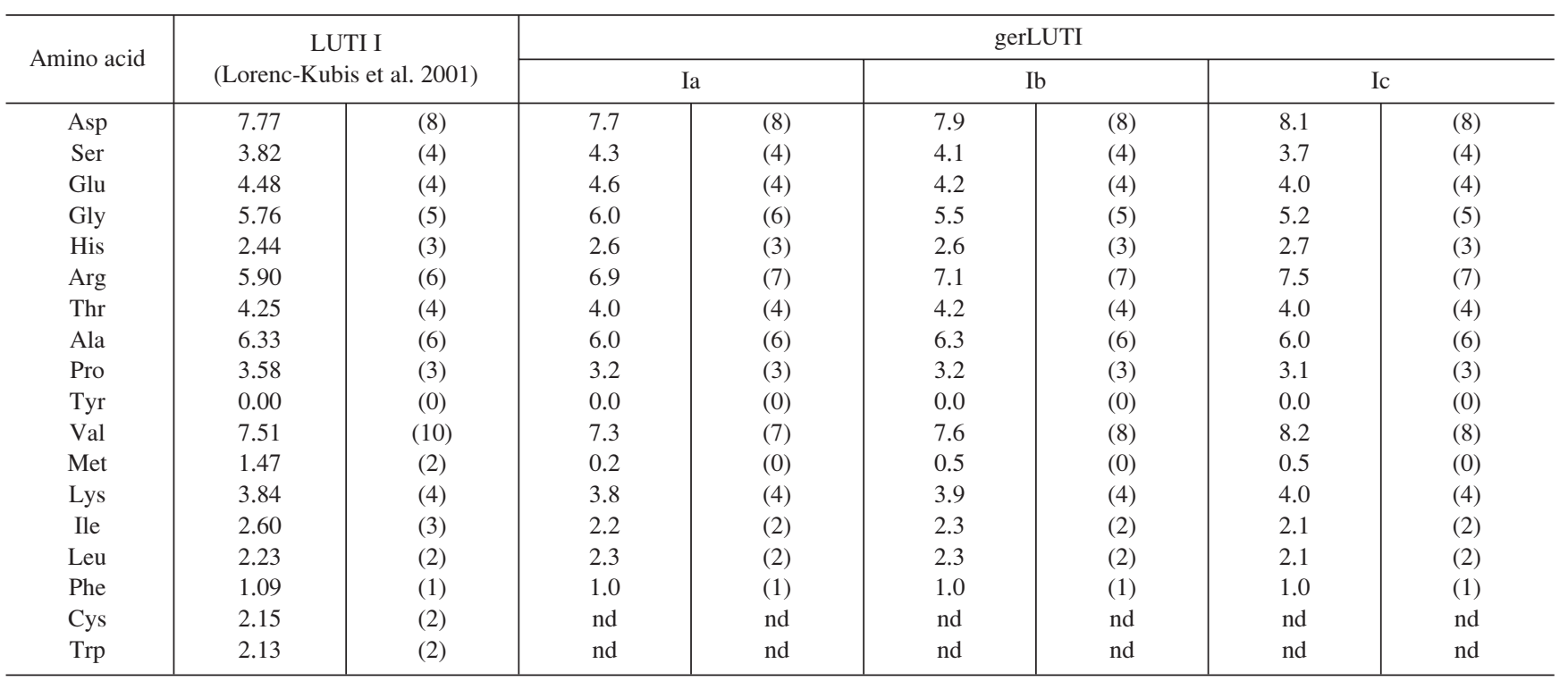


10

20

30

40

$\downarrow \quad 50$

60

69

<SRRCPGKNAWPELVGKSGNMAAATVERENRNVHAIVLKEGSAMTKDFRCDRVWVIVNDHGVVTSVPHIT

Fig. 7. Amino acid sequence of LUTI (Lorenc-Kubis et al. 2001). The $\mathrm{P}_{1}$ residue of the reactive site and methionine residues as a possible (potential) place of oxidation are indicated by an arrowhead and stars, respectively.

$16.8 \pm 3 \mathrm{Da})$, and a few minor peaks, e.g. with molecular masses of 7687 (plus 33.6 \pm 3 Da) (Fig. 6).

The 14.6 to $33.6 \pm 3$ Da increase in the molecular masses of LUTI indicate that during flax seeds germination some selective modification of inhibitor molecules took place, e.g. oxidation of one or two methionine residues. This observation correlated with the decrease in the methionine contents of the gerLUTI Ib and Ic (Table 1). The oxidation of the inhibitor molecule during germination might precede its proteolytic breakdown and might be a crucial process in the proteolytic degradation pathway at least for some storage proteins.

In the preparation of gerLUTI Ib (Fig. 6) one could observe several additional small peaks with gradually increasing molecular masses, as compared to LUTI from the resting seeds This might indicate that the catabolism of the inhibitor occurs in a more complicated way, finally yielding the modified peptide products with a definite, by not yet known, function, connected, for example, with the regulation of the germination process.

\section{LITERATURE CITED}

CHRISPEELS M., BAUMGARTNER B. 1978. Trypsin inhibitor in mung bean cotyledons. Purification, characteristics, subcellular localization and metabolism. Plant Physiol. 61: 617- 623.

CIERPICKI T., OTLEWSKI J. 2000. Determination of a high precision structure of a novel protein, Linum usitatissimum trypsin inhibitor (LUTI) using computer-aided assignment of NOESY cross-peaks. J. Mol. Biol. 302: 1179-1192.

COHEN S.A., MICHAUD D.F. 1993. Synthesis of a fluorescent derivatizing reagent 6 -aminoquinolyl- $N$-hydroxysuccinimidyl carbamate, and its application for the analysis of hydrolysate amino acids via high-performance liquid chromatography. Anal. Biochem. 211: 279-287.

ERLANGER B.F., KOKOVSKY N., COHEN W. 1961. The preparation and properties of two new chromogenic substrates of trypsin. Arch. Biochem. Biophys. 95: 271-278.

GOA J. 1953. A microbiuret method for protein determination. Determination of total protein in cerebrospinal fluid. Scand. J. Clin. Lab. Invest. 5: 218-222.

HEJGAARD J., DAM J., PETERSEN L.C., BJORN S.E. 1994. Primary structure and specificity of the major serine proteinase inhibitor of amaranth (Amaranthus caudatus L.) seeds Biochim. Biophys. Acta 1204: 68-74.
LORENC-KUBIS I., KOWALSKA J., POCHROŃ B., ŻUŻŁO A., WILUSZ T. 2001. Isolation and amino acid sequence of a serine proteinase inhibitor from common flax (Linum usitatissimum) seeds ChemBioChem 2: 100-106.

LUCKETT S., GARCIA R.S, BARKER J.J., KONAREV AL.V., SHEWRY P.R., CLARKE A.R., BRADY R.L. 1999. High-resolution structure of a potent, cyclic proteinase inhibitor from sunflower seeds J. Mol. Biol. 290: 525-533.

LUO M.-J., LU W.-Y., CHI C.-W. 1997. Clarification of a uncertain intron within the cDNA sequences of arrowhead proteinase inhibitors A and B. J. Biochem. 121: 991-995.

McGRAIN A.K., CHEN J.C., WILSON K.A., TAN-WILSON A.L. 1992. Proteases catalysing processing and degradation of Kunitz soybean trypsin inhibitor during seed maturation. Phytochemistry 31: 421-426.

NAGAWA Y., BENDER M.L. 1970. Methylation of histidine-57 in $\alpha$-chymotrypsin by methyl $p$-nitrobenzenesulfonate. A new approach to enzyme modification. Biochemistry 9: 259-267

PEPPER D.S. 1992. Some alternative coupling chemistries for affinity chromatography. In: Practical Protein Chromatography. A. Kenney S., Fowell S. (eds), pp. 181-183, The Humana Press, Totova, NJ.

RICHARDSON M. 1991. Seed storage proteins. The enzyme inhibitors. Methods Plant Biochem. 5: 259-305.6

SCHÄGGER H., VON JAGOW G. 1987. Tricine-sodium dodecyl sulfate-polyacrylamide gel electrophoresis for the separation of proteins in the range from 1 to $100 \mathrm{kDa}$. Anal. Biochem. 166: 368-379.

VOLPICELLA M., SCHIPPER A., JONGSMA M.A., SPATO N., GALLERANI R., CECI L.R. 2000. Characterization of recombinant mustard trypsin inhibitor 2 (MTI2) expressed in Pichia pastoris. FEBS Lett. 468: 137-141.

WIECZOREK M., OTLEWSKI J., COOK J., KEVIN P., LELUK J., WILIMOWSKA-PELC A., POLANOWSKI A., WILUSZ T., LASKOWSKI M. Jr. 1985. The squash family of serine proteinase inhibitors. Amino acid sequences and association equilibrium constants of inhibitors from squash, summer squash, zucchini, and cucumber seeds Biochem. Biophys. Res. Commun. 126: 646-652.

WILIMOWSKA-PELC A., MEJBAUM-KATZENELLENBOGEN W. 1978. A simple method for isolating trypsin from trichloroacetic acid extracts of bovine pancreas. Anal. Biochem 90: 816-20.

WOLF P. 1983. A critical reappraisal of Waddell's technique for ultraviolet spectrophotometric protein estimation. Anal. Biochem. 129: 145-155.

WOLFSON J.L., MURDOCK L.L. 1995. Potential use of protease inhibitors for host plant resistance: a test case. Environ. Entomol. 24: 52-57. 


\section{CZY UTLENIENIE RESZT METIONINY \\ POPRZEDZA INAKTYWACJE INHIBITORA TRYPSYNY (LUTI) \\ W KIEŁKUJĄCYCH NASIONACH LNU ZWYCZAJNEGO (LINUM USITATISSIMUM)?}

\section{STRESZCZENIE}

Badano aktywność antytrypsynową w kiełkujących nasionach lnu (Linum usitatissimum). W początkowym stadium kiełkowania obserwowano wzrost, a w dalszym etapie rozwoju siewek, spadek aktywności antytrypsynowej. Z sześciodniowych siewek wydzielono inhibitor trypsyny (gerLUTI). W procesie oczyszczania zastosowano frakcjonowanie białek homogenatu alkoholem oraz chromatografię na CM-Sephadex C-25, immobilizowanej metylochymotrypsynie w obecności $5 \mathrm{M} \mathrm{NaCl}$ i w końcowym etapie na kolumnie $\mathrm{C}_{18} \mathrm{w}$ RP-HPLC.

GerLUTI w SDS-PAGE wędruje w postaci pojedynczego pasma, ale w spektrometrii masowej wykazuje obecność co najmniej trzech form o masie cząsteczkowej $7654 \pm 3 \mathrm{Da}, 7668 / 7670 \pm 3 \mathrm{Da}$, oraz $7687 \pm 3 \mathrm{Da}$. Preparat LUTI uzyskany z nasion spoczynkowych posiada tylko jedną formę o masie cząsteczkowej $7655 \pm 3 \mathrm{Da}$. Preparaty LUTI i gerLUTI różnią się również zawartością metioniny. LUTI posiada 2 reszty metioniny, podczas gdy w gerLUTI wykazano zaledwie ślad metioniny. Uzyskane wyniki sugerują, że w procesie kiełkowania nasion lnu cząsteczka inhibitora ulega selektywnej modyfikacji np. poprzez utlenienie reszt metioniny, a proces ten poprzedza proteolityczną degradację tego białka.

SŁOWA KLUCZOWE: Siewki lnu zwyczajnego (Linum usitatissimum), inhibitory trypsyny, białka, kiełkowanie, immobilizowana metylowana chymotrypsyna, spektrometria masowa. 